\title{
Importance of irrigation and plant size in the establishment success of different native species in a degraded ecosystem of central Chile
}

\author{
Importancia del riego y tamaño de las plantas en el éxito de establecimiento de \\ diferentes especies nativas en un ecosistema degradado de Chile central
}

\author{
Pablo I Becerra ${ }^{a *}$, Gustavo Cruz b , Santiago Ríos c, Giorgio Castelli b,c

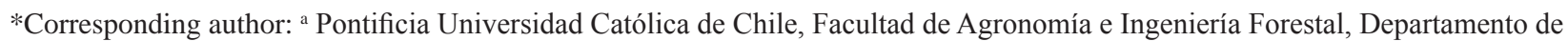 \\ Ecosistemas y Medio Ambiente. Avenida Vicuña Mackenna 4860, Santiago, Chile, phone/fax: 56-2-26864169, pablobecerra@uc.cl \\ ${ }^{\mathrm{b}}$ Universidad de Chile, Facultad de Ciencias Forestales y de Conservación de la Naturaleza, \\ Departamento de Silvicultura, Santiago, Chile. \\ c Mitiga Ltda. Servicios Forestales, Monseñor Escriva de Balaguer 14331, Lo Barnechea, Santiago, Chile.
}

\begin{abstract}
SUMMARY
Irrigation has frequently been considered a necessary step in reforesting open areas of semiarid ecosystems. However, the success of irrigation has mainly been assessed using young and small plants, typically younger than two years old. Few studies have explored whether irrigation is also important with older and larger plants, and if the use of larger plants may enhance reforestation success. We tested the effect of irrigation and plant size on survival and height growth of six tree species from the Mediterranean region of Chile, for planting on a reclaimed fly ash landfill lacking woody vegetation. Between 2008 and 2010 we planted and monitored 160 plants of each species in a factorial design including 1- and 4-year-old trees (smaller and larger, respectively), with and without irrigation. Irrigation improved survival in more water-demanding species regardless of plant size, and primarily among smaller plants for species classified in the middle of a water requirement gradient. With more drought-resistant species, irrigation was not important for survival. The use of larger plants enhanced survival but not growth, and mainly in more water-demanding species. In general, height growth for some species was higher with irrigation and mainly among smaller plants.
\end{abstract}

Key words: plant age, growth rate, restoration, sclerophyllous forest, survival.

\section{RESUMEN}

El riego ha sido frecuentemente considerado un paso necesario en la reforestación de áreas abiertas de ecosistemas semiáridos. Sin embargo, el éxito del riego ha sido evaluado principalmente usando plantas jóvenes, típicamente menores de un año de edad. Muy pocos estudios han explorado si el rol del riego es también importante en plantas de mayor edad y tamaño y si el uso de plantas más grandes incrementa el éxito de procesos de reforestación. En este estudio se evalúa el efecto del riego y del tamaño de las plantas en la sobrevivencia y crecimiento en seis especies arbóreas de la región Mediterránea de Chile sobre un área de depósitos de cenizas residuales de carbón mineral. Entre 2008 y 2010 se llevó a cabo un experimento en el cual se plantaron y monitorearon 160 plantas de cada especie en un diseño factorial, incluyendo plantas de 1 y 4 años de edad, con y sin riego. Los resultados indican que el riego mejoró la sobrevivencia independiente de la edad en las especies más demandantes de agua, y principalmente en las plantas más jóvenes en especies clasificadas como intermedias en un gradiente de requerimiento de agua. En especies más resistentes a la sequía, el riego no fue importante. El uso de plantas de mayor tamaño incrementó la probabilidad de sobrevivencia pero no el crecimiento, también principalmente en especies más demandantes de agua. El crecimiento en altura fue en general mayor con riego y en plantas más grandes en algunas especies.

Palabras clave: edad de planta, tasa de crecimiento, restauración, bosque esclerófilo, sobrevivencia.

\section{INTRODUCTION}

During the last few centuries, natural ecosystems have been highly disturbed by human actions, and restoration has become more important for the conservation of threatened species and degraded ecosystems (Van Andel and Aronson 2006). This is the case of the original vegetation in the Mediterranean-type climate region of central Chile (between $27^{\circ}$ and $38^{\circ} \mathrm{S}$ ), which has been altered by prolonged anthropic activity such as burning, pasturing, intensive agriculture, expansion of population centers and mining (Fuentes and Hajek 1979). In these cases reforestation may serve as the primary means for restoring these ecosystems.

Several abiotic and biotic factors may influence restoration of plant species, and past studies have included different reforestation techniques for dealing with these to improve survival and growth (Van Andel and Aronson 2006). In semiarid regions with Mediterranean-type climates, water availability has been considered the main abiotic factor limiting regeneration and restoration success (Rey-Benayas 
et al. 2002, Holmgren et al. 2006, Squeo et al. 2007, Padilla and Pugnaire 2009, Siles et al. 2010, Becerra et al. 2011). To counteract water constraints, reforestation programs often include expensive treatments such as irrigation, at least during the first years after planting (Altamirano 2008). Hence, understanding what techniques can enhance survival and growth in dry ecosystems, and also reduce the need of irrigation, is crucial for planning restoration of drylands.

A factor that may affect the level of water needs, and also influence survival and growth, is the size of plants at the planting time. Size commonly depends on age, and tolerances and ecophysiological requirements of many woody species appear to shift during ontogeny and then with the size of plants (Rey and Alcántara 2000, Lusk 2004, Siles et al. 2010). In fact, Siles et al. (2010) found that in a Mediterranean ecosystem in Spain, the survival rate of 2-year-old plants was greater than that of 1-year-old plants in several species. Also, some older plants grew faster than younger ones. Older and larger plants (saplings) have larger root systems and may survive and grow better than smaller ones in moisture-poor environments. They also have a larger leaf area which may increase photosynthesis and growth, although water losses by transpiration may also be superior. Yet where water is more abundant, differences in stress tolerance between larger and smaller plants may be less important.

Most of the experimental studies assessing the benefits of irrigation to improve the establishment of trees have used only seedlings younger than 2 years old (Holmgren et al. 2006, Squeo et al. 2007, Padilla and Pugnaire 2009). Few studies involving irrigation compared survival and growth among plants of different ages and sizes (Radomiljac 1998, Siles et al. 2010). We assessed effects of both irrigation and plant size on survival and growth of six different native tree species on a reclaimed fly ash landfill in central Chile. We predicted that irrigation would enhance survival and growth, mainly of smaller plants, and that survival and growth would be higher in larger plants, especially under conditions of water scarcity.

\section{METHODS}

Study area. The study was conducted in a coastal area of central Chile, near the town of Puchuncaví (32 $45^{\circ} 45^{\prime}$, $\left.\mathrm{S} ; 71^{\circ} 24^{\prime} 58^{\prime \prime} \mathrm{W}\right)$ at a reclaimed fly ash landfill site belonging to AES Gener S.A. The climate is Mediterranean semi-arid, with 6-7 dry months, a mean annual precipitation of $370 \mathrm{~mm}$ and a mean annual temperature of $14^{\circ} \mathrm{C}$ (di Castri and Hajek 1976). During the years of the study, rainfall was $204 \mathrm{~mm}$ in 2008 (from the date of planting in August through December), $442 \mathrm{~mm}$ in 2009, and $362 \mathrm{~mm}$ in 2010. In this area, $80-90 \%$ of the precipitation occurs between June and September (di Castri and Hajek 1976).

The area adjacent to the experimental site is dominated by sclerophyllous forest with pioneer tree species such as Acacia caven, Maytenus boaria Mol., Quillaja saponaria Mol., Lithrea caustica (Mol.) H. et A., Schinus latifolius
(Gill. ex Lindl.) Engler., Schinus polygamus (Cav.) Cabr., and Kageneckia oblonga R. et P.; and late-successional tree species such as Peumus boldus Mol. and Cryptocarya alba (Mol.) Looser. By contrast, the experimental site had been highly disturbed to serve as a landfill for a nearby energy production facility. Woody vegetation had been cut and a layer of the natural soil approximately $3 \mathrm{~m}$ in depth was removed and preserved nearby. After that, a layer of approximately $8 \mathrm{~m}$ of residual ash from energy production based on mineral coal was deposited in the excavated area, and eventually covered with an approximately $0.8 \mathrm{~m}$ layer of soil previously extracted from the site. Thereafter, a continuous herbaceous layer became naturally established across the surface (approx. $90 \%$ cover).

Because of this management, the physical structure of the soil was completely modified compared to that of the adjacent undisturbed areas. The chemical and physical properties of this type of residue have been documented by Dellantonio et al. (2008). Within the experimental site, we found that soil $\mathrm{pH}$, organic matter and phosphorous were significantly higher at a depth of $1 \mathrm{~m}$ (in the ash stratum) than at a depth of $0.2 \mathrm{~m}$ (table 1 ). In addition, organic matter and phosphorous were also significantly higher than in the adjacent area, but only at a depth of $1 \mathrm{~m}$. In general, soil characteristics in the stratum in which plants were planted (higher) did not differ significantly between the experimental site and the adjacent natural areas (table 1).

Plant material. For the experimental planting we used Maytenus boaria, Quillaja saponaria, Lithrea caustica, Schinus latifolius, Schinus polygamus and Kageneckia oblonga. These are shade-intolerant or semi-tolerant pioneer species common to the entire Mediterranean region of Chile (Rodríguez et al. 1983).

Plants were obtained from a typical commercial greenhouse (Vivero y Jardín Pumahuida Ltda.), located on the northern area of Santiago, Chile, where they were grown from seeds collected in central Chile, primarily near Santiago. We obtained plants of two different sizes, using ones of different ages with each species. Smaller (1 year old) and larger (4 year old) plants were produced from seeds collected at the same localities, although in different years.

All plants were cultivated in sand mixed (80:20) with soil collected from native forests, grown under shade (50\%), and irrigated to keep the soil permanently humid. No plant was fertilized in the greenhouse, nor acclimated before transplanting. The production process in this and many other greenhouses is to first sow individuals seeds in small containers (1.5 L, $5 \mathrm{~cm}$ radius, $20 \mathrm{~cm} \mathrm{depth),} \mathrm{grow}$ the seedlings for 1 year, and then transplant them into larger containers (10 L, $10 \mathrm{~cm}$ radius, $32 \mathrm{~cm}$ depth). Consequently, the older plants had a larger root systems and longer shoots. Height at planting (mean $\pm 1 \mathrm{SD}$ ) for smaller and larger plants, respectively, was $48.1 \pm 9.7 \mathrm{~cm}$ and $207.7 \pm 20.8 \mathrm{~cm}$ for Q. saponaria, $14.5 \pm 2.9 \mathrm{~cm}$ and $64.2 \pm 13.2 \mathrm{~cm}$ for K. oblonga, $25.0 \pm 6.0 \mathrm{~cm}$ and $48.1 \pm 13.3 \mathrm{~cm}$ for $L$. caus- 
Table 1. Soil characteristics at lower $(1 \mathrm{~m})$ and higher $(0.2 \mathrm{~m})$ depths in the experimental site and adjacent natural habitat $(\mathrm{N}=3$ for each depth and site). Soil samples were randomly collected within each site. Different lower-case and upper-case letters indicate significant statistical differences (ANOVA, LSD post-hoc tests, $P<0.05$ ) between depth levels for a single site and between sites for a single depth, respectively.

Características del suelo en dos profundidades: profunda $(1 \mathrm{~m})$ y superficial $(0,2 \mathrm{~m})$ en el sitio de la plantación experimental y en un área aledaña de vegetación natural remanente $(\mathrm{N}=3$ para cada profundidad y sitio). Las muestras de suelo fueron colectadas aleatoriamente dentro de cada sitio. Diferentes letras minúsculas y mayúsculas indican respectivamente diferencias estadísticas significativas (ANDEVA, prueba a posteriori LSD, $P<0,05)$ entre niveles de profundidad dentro de un sitio y entre sitios para un particular nivel de profundidad.

\begin{tabular}{lcccccc}
\hline \multicolumn{1}{c}{ Site } & Soil depth & $\mathrm{pH}$ & $\begin{array}{c}\text { Organic matter } \\
(\%)\end{array}$ & $\begin{array}{c}\text { Nitrogen } \\
\left(\mathrm{mg} \mathrm{kg}^{-1}\right)\end{array}$ & $\begin{array}{c}\text { Phosphorus } \\
\left(\mathrm{mg} \mathrm{kg}^{-1}\right)\end{array}$ & $\begin{array}{c}\text { Potassium } \\
\left(\mathrm{mg} \mathrm{kg}^{-1}\right)\end{array}$ \\
\hline Plantation & Lower & $8.26 \pm 0.12^{\mathrm{Aa}}$ & $7.79 \pm 1.24^{\mathrm{Aa}}$ & $10.00 \pm 2.08^{\mathrm{Aa}}$ & $34.00 \pm 4.93^{\mathrm{Aa}}$ & $70.00 \pm 8.72^{\mathrm{Aa}}$ \\
Plantation & Higher & $6.72 \pm 0.07^{\mathrm{Ab}}$ & $1.10 \pm 0.10^{\mathrm{Ab}}$ & $8.00 \pm 1.73^{\mathrm{Aa}}$ & $9.00 \pm 1.00^{\mathrm{Ab}}$ & $129.33 \pm 22.15^{\mathrm{Aa}}$ \\
Natural habitat & Lower & $7.18 \pm 0.35^{\mathrm{Aa}}$ & $0.79 \pm 0.36^{\mathrm{Ba}}$ & $6.33 \pm 1.20^{\mathrm{Aa}}$ & $3.00 \pm 1.53^{\mathrm{Ba}}$ & $81.67 \pm 15.07^{\mathrm{Aa}}$ \\
Natural habitat & Higher & $5.67 \pm 0.49^{\mathrm{Ab}}$ & $2.48 \pm 0.18^{\mathrm{Aa}}$ & $11.00 \pm 3.79^{\mathrm{Aa}}$ & $8.67 \pm 1.45^{\mathrm{Aa}}$ & $118.33 \pm 15.86^{\mathrm{Aa}}$ \\
\hline
\end{tabular}

tica, $30.6 \pm 6.2$ and $184.4 \pm 19.6 \mathrm{~cm}$ for S. latifolius, $28.6 \pm$ $7.1 \mathrm{~cm}$ and $108.7 \pm 13.5 \mathrm{~cm}$ for $S$. polygamus and $15.5 \pm 3.3$ and $166.4 \pm 18.2 \mathrm{~cm}$ for M. boaria.

Experimental design. In August of 2008, we planted 960 trees of the six species (160 individuals per species) in a regular distribution with $3 \mathrm{~m}$ spacing between adjacent individuals. Each tree was planted in a previously dug hole that was $40 \mathrm{~cm}$ deep and $40 \mathrm{~cm}$ in diameter. The 160 individuals of each species were divided evenly into treatment groups based on plant size and irrigation as follows: 80 smaller and 80 larger trees of each species, with half of each size group irrigated. The $6 \times 2 \times 2$ factorial experiment included species (6), irrigation (2), and size (2) as factors; with 40 individuals of each species per treatment group. In addition, areas where ash residues are deposited after coalbased energy production typically are flat or sloped (up to $10 \%$ ). To explore possible differences, we installed $30 \%$ of replicates $(\mathrm{N}=12$ per species per treatment group) in a sloped area, and $70 \%(\mathrm{~N}=28$ per species per treatment group) in a flat one. We included these two conditions (flat and sloped) as blocks in the statistical analyses.

The experimental site was protected from cattle by a fence $1.5 \mathrm{~m}$ in height enclosing the entire $100 \mathrm{~m}$ x $300 \mathrm{~m}$ area, and each plant was additionally protected by a wire mesh fence $0.5 \mathrm{~m}$ in height. We distributed plants in rows of 32 individuals, using one species for the first 16, and another species for the second 16. The other four species were arranged in the same way in two adjacent rows, creating a group with three rows. We installed 10 of these threerow groups having 160 individuals per species, with nine rows in the sloped area (288 plants overall) and 21 rows in the flat area (672 plants overall). All rows were oriented parallel to the slope (along the contour). Each species was located on the right section of the row in five rows, and on the left section in the other five rows. Within each group of 16 individuals per species, we planted eight smaller and larger plants alternately. For each group of 16 individuals per species in each row, we irrigated plants in alternate groups of four plants (including two smaller and two larger plants) with two irrigated and two non-irrigated groups of four plants. This spatial design allowed us to distribute species and treatments throughout the entire study area, and to economize the design of our irrigation system.

Once a month from October to April of each year, irrigated plants received $8 \mathrm{~L}$ of potable water applied to a $0.25 \mathrm{~m}$ radius around the base. In the sloped area, irrigated plants were in the same positions in every row. This insured that the irrigated plants in one row were exactly above or below those plants in the next row. Thus, if irrigation resulted in some underground downslope movement of water across rows (surface runoff did not occur), this water always reached another irrigated plant, and non-irrigated plants did not receive water originated by any subsurface flow initiated by the irrigation. In the flat area, we found no signs that surface runoff occurred. If water spread underground, it was probably slight.

We monitored survival once per month from the planting date (August, 2008) through the end of the experiment (September, 2010), and assessed the height (from the soil to the tip of the longest shoot) of each plant in September of 2009 and September of 2010. During August and September 2008 after planting, some individuals within the flat area were flooded when water from winter rainfall accumulated in the planting holes. Water remained in the holes for approximately one month, and some flooded seedlings died. Those same holes flooded again the following year, but no living plants were affected, as plants in the flooded holes died during the first year.

Statistical analyses. Comparison of survival between flooded and non-flooded plants within the flat area was performed using a generalized lineal model (GLM) that included flooding, species, and their interaction as factors. Further analyses, including the originally planned assessment of effects on survival and growth based on size and irrigation, were performed using only those individuals that survived the flooding. Because no plants in the sloped area were 
flooded, the number per species for that area remained at 48 $(\mathrm{N}=12$ per treatment group per species). To balance the sample sizes across groups within the flat area, we randomly decreased the sample to 10 plants per species per treatment group (40 plants per species and 240 plants overall), as this was the lowest number of plants that survived flooding for any species in any one treatment group. Similarly, because of mortality during the experiment and to balance the number of replicates among treatments for the analysis of growth, we equated all sample sizes to the lowest number of surviving plants of any one species remaining in any one treatment. To do this, we randomly selected living individuals until the criterion sample size, in this case five plants, was reached for each species per treatment group.

We assessed effects of the experimental factors two years after planting. Survival was analyzed using a generalized lineal model that included irrigation, size, and species as factors, with topographic position (sloped or flat) as a blocking factor, and individual plants as replicates (dead or alive; the binomial link function was used). Similarly, the effects on growth in height were analyzed using a generalized lineal model that included the same factors (but only living individuals). Growth was evaluated using the absolute difference of height $(\mathrm{cm})$ between September 2010 and September 2008. Though growth data were distributed normally, some individuals decreased in height and lost biomass during the 2-year growth period. Hence we used a power link function in the statistical analysis. All statistical analyses were performed using SPSS 15.0.

\section{RESULTS}

Effects of flooding on survival. No plant located in the sloped area was affected by flooding. Among those on the flat area (672), 221 (32.89\%) were flooded, and of these, 118 (53.4\%) survived. Among the non-flooded plants $(\mathrm{N}=451)$, $383(84.9 \%)$ survived through the first two months. S. latifolius and $S$. polygamus were the most resistant to flooding, with $89.7 \%$ and $87.5 \%$ survival, respectively. K. oblonga was the least resistant to flooding, with only $2 \%$ of flooded plants surviving.

We observed differences in survival between species as early as two months after planting $\left(\chi^{2}=165.93, P<0.001\right.$; figure 1). In general, flooding significantly reduced plant survival $\left(\chi^{2}=66.92, P<0.001\right)$. However, we found a significant interaction between flooding and species $\left(\chi^{2}=18.40\right.$, $P=0.002)$. With K. oblonga, L. caustica and Q. saponaria, flooded plants had significantly lower survival than nonflooded plants, but the other species were not significantly affected by flooding (figure 1).

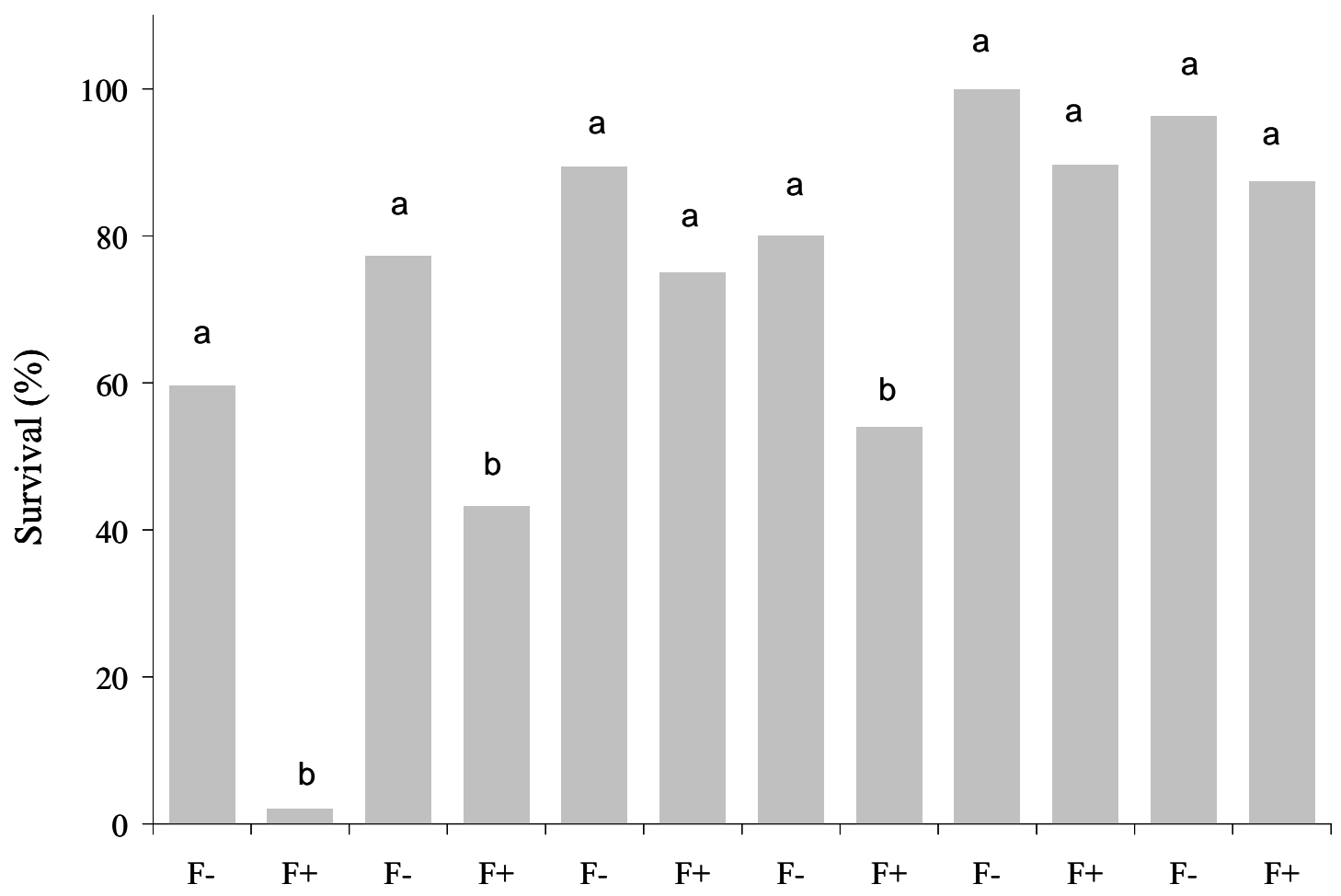

Figure 1. Survival by species two months after planting. Total $\mathrm{N}$ per species $=160, \mathrm{~N}$ of flooded individuals per species varied between 30 and 50, F+: flooded, and F-: not flooded. $\mathrm{N}$ of not-flooded individuals per species varied between 110 and 130 . Different lower-case letters indicate significant statistical differences (GLM, LSD post-hoc tests, $P<0.05$ ) between flooding conditions within a single species.

Porcentaje de sobrevivencia de plantas después de la inundación (F+: inundada, F-: no inundada) de cada especie dos meses después de la plantación. $\mathrm{N}$ total por especie $=160, \mathrm{~N}$ de inundados por especie varió entre 30 y $50, \mathrm{~N}$ de plantas no inundadas por especie varió entre 110 y 130 . Diferentes letras minúsculas indican diferencias estadísticas significativas (GLM, prueba a posteriori LSD, $P<0,05$ ) entre condiciones de inundación para una especie particular. 
Effects of experimental factors on plant survival. Altogether, 501 plants were alive in the flat area two months after planting (118 flooded, plus 383 non-flooded plants). To balance the experiment, we used 240 plants, including 31 that were flooded. For the whole experiment (including 240 plants from the flat area, plus 288 from the sloped area, or 528 plants overall), only $5.87 \%$ were flooded.

We found significant differences in survival among species, sizes, and irrigation treatments at the end of the 2-year experiment (table 2). The block alone had no effect, but we found a significant interaction between block and species, indicating that the survival of some species differed between topographical positions. Specifically, M. boaria survival was significantly superior in sloped areas $(68.18 \%)$ than in flat areas $(47.52 \%$; Fisher's least significant difference (LSD) post-hoc test, $P<0.05$ ), and survival of S. latifolius in flat areas ( $95.37 \%$ ) was significantly higher than in sloped areas $(78.26 \%$; LSD post-hoc test, $P<0.05$ ). Survival of the other species did not differ between blocks. Interactions between block and plant size, or between block and irrigation, were not statistically significant (table 2), indicating that topographic position in itself had no influence on the effect of these experimental factors

Table 2. Survival (GLM analyses, binomial distribution and logit link function) two years after planting in response to irrigation (with and without summer irrigation), plant size (smaller and larger plants), species and block (slope and flat area). $\mathrm{N}$ values per combination of species, irrigation and size were 12 for the slope area and 10 for the flat area (see methods for more explanation).

Resultados estadísticos de sobrevivencia (análisis GLM, usando distribución binomial y función link tipo logit) dos años después de la plantación para el efecto del riego (con y sin riego), tamaño de plantas (pequeñas y grandes), especie y bloque (área plana y con pendiente). Los valores de $\mathrm{N}$ por combinación de especie, riego, tamaño fueron 12 para el área inclinada y 10 para el área plana.

\begin{tabular}{lcrr}
\hline Source of variation & d. f. & \multicolumn{1}{c}{$\chi^{2}$} & \multicolumn{1}{c}{$P$} \\
\hline Block & 1 & 1.01 & 0.315 \\
Species & 5 & 129.27 & $<0.001$ \\
Irrigation & 1 & 16.81 & $<0.001$ \\
Size & 1 & 30.91 & $<0.001$ \\
Species x Block & 5 & 17.37 & 0.004 \\
Irrigation x Block & 1 & 3.38 & 0.070 \\
Size x Block & 1 & 0.95 & 0.329 \\
Species x Irrigation & 5 & 29.86 & $<0.001$ \\
Species x Size & 5 & 12.68 & 0.026 \\
Irrigation x Size & 1 & 0.49 & 0.483 \\
Species x Irrigation x Block & 5 & 5.27 & 0.384 \\
Species x Size x Block & 5 & 3.57 & 0.612 \\
Species x Irrigation x Size & 5 & 8.47 & 0.132 \\
Irrigation x Size x Block & 1 & 0.16 & 0.688 \\
Species x Irrigation x Size & 5 & 3.96 & 0.265 \\
x Block & & & \\
\hline
\end{tabular}

for any species. Consequently, we pooled both blocks in figure 2 to illustrate survival in the experimental treatments.

We found significantly greater survival among larger plants $(77.83 \%)$ than among smaller ones $(62.61 \%)$, and that survival of irrigated plants $(77.57 \%)$ was significantly higher than that of non-irrigated ones $(64.30 \%$; figure 2$)$. We also detected a significant interaction between size and species (table 2), indicating that larger plants had a higher probability of survival only in some species (figure 2). Similarly, we observed a significant interaction between irrigation and species (table 2), indicating that irrigation enhanced survival for only some species (figure 2). We observed significantly higher survival for larger plants of M. boaria regardless of irrigation treatment. For K. oblonga, Q. saponaria and S. latifolius, larger plants survived better than smaller ones, but only without irrigation (figure 2). For $K$. oblonga and $M$. boaria, irrigation enhanced the survival of both smaller and larger plants; while irrigation increased the survival only of smaller plants for $S$. latifolius. In the other species, irrigation had no significant effect on survival (figure 2). The three highest survival rates were observed in non-irrigated larger plants of S. latifolius $(97.5 \%)$ and S. polygamus $(97.4 \%)$, and with irrigated larger plants of S. polygamus $(95.0 \%)$.

Effects of experimental factors on plant growth. We observed significant differences in growth of plants based on species, size, and irrigation treatment (table 3 ). But we found no significant effect of block and no significant interactions between block and other factors, indicating that topographic position had no influence on growth of surviving plants or on other factors that might affect growth. Therefore we pooled the data from sloped and flat areas in figure 3 to illustrate differences in growth among treatment groups for each species.

The growth (mean $\pm 1 \mathrm{SE})$ of irrigated plants $(0.19 \pm$ 0.02 ) was significantly higher than that of non-irrigated plants $(0.08 \pm 0.02)$. Furthermore, growth of smaller plants $(0.35 \pm 0.02)$ significantly exceeded that of larger plants $(0.001 \pm 0.01)$. However, we observed a significant statistical interaction between species and size (table 3). Smaller plants grew significantly faster than larger ones only for M. boaria, K. oblonga, S. polygamus, and S. latifolius (figure 3). Furthermore, irrigation enhanced the growth only of smaller plants of $K$. oblonga and S. latifolius, and only among larger plants of S. polygamus (figure 3 ). For the other three species, irrigation had no significant effect on growth. The three highest growth rates were observed with irrigated smaller plants of $K$. oblonga, and non-irrigated and irrigated smaller plants of $M$. boaria (figure 3).

\section{DISCUSSION}

Flooding caused mortality of some plants during the first two months after planting in this experiment, but only in the flat area where rainwater accumulated in the plan- 


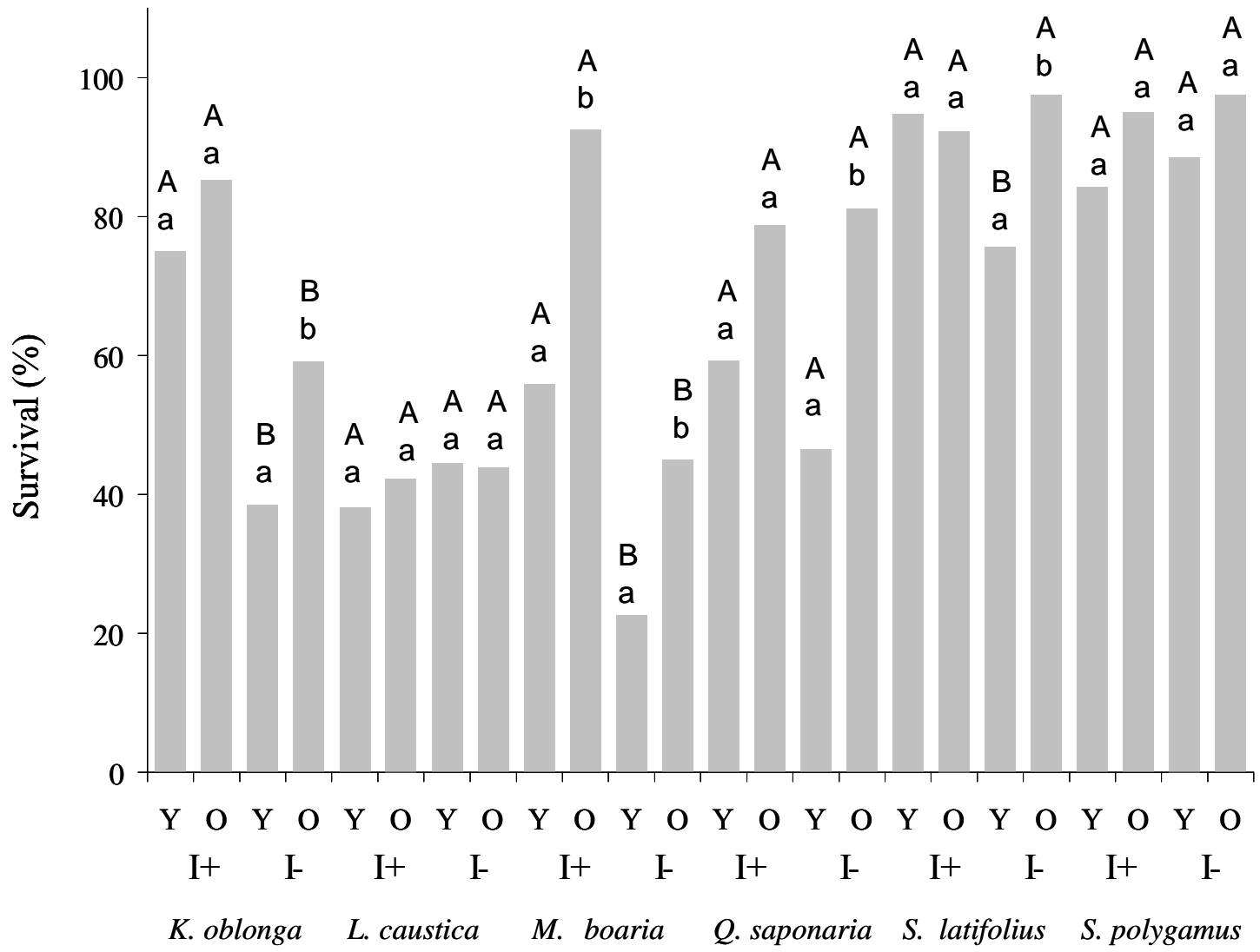

Figure 2. Survival per species two years after planting (Y: smaller or 1-year-old plants, O: larger or 4-year-old plants; I+: with irrigation, I-: without irrigation). Different lower-case and upper-case letters indicate significant statistical differences (GLM, LSD post-hoc tests, $P<0.05$ ) between plant sizes within a single species and irrigation treatment, and between irrigation treatments within a single species and size, respectively.

Porcentaje de sobrevivencia por especie dos años después de la plantación (Y: plantas pequeñas de un año; O: plantas grandes de cuatro años; I+: con riego; I-: sin riego). Diferentes letras minúsculas y mayúsculas indican respectivamente diferencias estadísticas significativas (GLM, test a posteriori LSD, $P<0,05$ ) entre tamaños de planta dentro de una particular especie y tratamiento de riego, y entre tratamientos de riego dentro de una particular especie y tamaño.

ting holes, and likely due to impeded percolation through the ash substrate (Neuschütz et al. 2006, Haynes 2009). Thus, a first step in the restoration of areas on this type of substrate would be to confirm that the layer of original soil laid down over the ash is adequately thick ( $>1 \mathrm{~m}$ deep) to insure good drainage in the rooting zone. Alternatively, reclaimed landfill sites could have a slight slope throughout to minimize water accumulation on the surface.

Several studies have shown that in semiarid regions such as Mediterranean areas, irrigation enhances the survival and growth of both naturally seeded vegetation and plantations (Rey-Benayas et al. 2002, Pardos et al. 2005, Holmgren et al. 2006, Squeo et al. 2007, Siles et al. 2010). Moreover, some recent studies indicate that higher water availability improves survival and growth when supplied during the warm season (Holmgren et al. 2006, Squeo et al. 2007, Siles et al. 2010). Consistent with these reports, irrigation in our study enhanced survival regardless of the plant size in two species (K. oblonga and M. boaria), and primarily among smaller trees of $S$. latifolius. In addition, irrigation increased the growth rate of smaller plants for $K$. oblonga and S. latifolius. However, irrigation did not enhance survival and growth of all species.

Our study area was located in a coastal area where clouds occur more frequently than in the more xeric interior and northern Mediterranean region of Chile (di Castri and Hajek 1976). Further, coal ash buried beneath the top soil layer frequently enhances water retention (Adriano and Weber 2001), and might have increased the soil moisture availability and improved survival of non-irrigated plants. Therefore, it is probable that species not affected by irrigation ( $L$. caustica, $Q$. saponaria and S. polygamus) were not significantly limited by water availability. Apparently, this is true for the more drought-resistant species (e.g. Brinks et al. 2011). For instance, S. polygamus has the northernmost and most xeric distribution of the six study species (Rodríguez et al. 1983). In addition, L. caustica and $Q$. saponaria are typically the only tree species found in the more xeric habitats within the region (Armesto and Pickett 1985). Accordingly, S. polygamus, L. caustica and 
Table 3. Statistical results (GLM analyses, normal distribution and power link function) for absolute height growth two years after planting in response to block (slope and flat areas), irrigation (with and without summer irrigation), size (smaller and larger), and species. All statistical analyses of growth were performed only with individuals alive two years after planting. The number of replicates was homogenized among treatments and species to $\mathrm{N}=5$ for each combination of treatments and block per species. Resultados estadísticos del crecimiento absoluto en altura (análisis GLM, usando distribución normal y función link tipo power) dos años después de la plantación para el efecto del riego (con y sin riego), tamaño de plantas (pequeñas y grandes), especie y bloque (área plana y con pendiente). Los valores de $\mathrm{N}$ fueron homogenizados a cinco plantas por combinación de especie, riego, tamaño y bloque.

\begin{tabular}{lccr}
\hline Source of variation & d. f. & \multicolumn{1}{c}{$\chi^{2}$} & \multicolumn{1}{c}{$P$} \\
\hline Block & 1 & 0.022 & 0.882 \\
Species & 5 & 22.91 & $<0.001$ \\
Irrigation & 1 & 12.46 & $<0.001$ \\
Size & 1 & 191.17 & $<0.001$ \\
Species x Block & 5 & 9.05 & 0.107 \\
Irrigation x Block & 1 & 0.77 & 0.381 \\
Size x Block & 1 & 0.58 & 0.443 \\
Species x Irrigation & 5 & 4.93 & 0.424 \\
Species x Size & 5 & 99.72 & $<0.001$ \\
Size x Irrigation & 1 & 1.55 & 0.212 \\
Species x Irrigation x Block & 5 & 3.66 & 0.598 \\
Species x Size x Block & 5 & 3.43 & 0.634 \\
Irrigation x Size x Block & 1 & 0.26 & 0.609 \\
Species x Irrigation x Size & 5 & 8.69 & 0.122 \\
Species x Irrigation x Size x & 5 & 4.61 & 0.466 \\
Block & & & \\
\hline
\end{tabular}

Q. saponaria probably have the greatest drought tolerance of the six study species. In contrast, species affected by irrigation, especially $M$. boaria, grow mainly in relatively moist habitats (Armesto and Pickett 1985). These findings suggest that geographical limits and habitat distribution may be good indicators of irrigation requirements of woody species at a given locality.

For water-demanding species (such as M. boaria and $K$. oblonga), both larger and smaller plants were positively affected by irrigation, suggesting that both sizes were water-limited. On the other hand, in less water-demanding species, (S. polygamus and L. caustica), neither larger or smaller plants were affected by irrigation, and apparently were not limited by water under environmental conditions of the experiment. For species classified in the middle of a water requirement gradient (e.g., S. latifolius, after Armesto and Pickett 1985), irrigation significantly influenced survival only for the smaller plants.

Many reforestation projects in central Chile include irrigation for only two or three years after planting (Altamirano 2008). Our results suggest that in more water-de- manding species, and especially for reforestation using 1-year-old plants of water demanding species, irrigation should last at least four years, although our data do not indicate how much longer irrigation should continue. With species classified in the middle of a water requirement gradient, irrigation of 1-year-old plants would be necessary only during the first year after planting. Probably irrigation is not necessary for more xerophytic species under conditions of substrate and climate similar to our experiment.

Some studies have documented ontogenetic shifts in the tolerances and ecophysiological requirements of woody species (Rey and Alcántara 2000, Lusk 2004), suggesting that the age and size at planting may influence the establishment success. Our results suggest that older and larger plants survive better than younger and smaller ones under non-irrigated conditions, but only among three of the six species studied (K. oblonga, Q. saponaria and $S$. latifolius). With $M$. boaria, larger plants survived better both with and without irrigation. Siles et al. (2010) also observed that the higher survival rate among older and larger plants depended on the abiotic conditions and species. In our study, the larger plants were taller and probably had larger root systems, potentially enhancing water uptake and survival (Lamhamedi et al. 1998, Radomiljac 1998). Thus, perhaps the size of the root system rather than age, per se, leads to greater survival of the older plants (Lamhamedi et al. 1998). However, this possibility needs additional research to clarify the effects of age and size. On the other hand, and counter to our hypothesis, larger plants did not grow faster than smaller ones. In fact, among four species (M. boaria. K. oblonga, S. latifolius and S. polygamus), smaller plants grew faster than the larger ones. It is probable that the abrupt change of environmental conditions from greenhouse to the experimental field has had a stronger impact in larger plants, losing biomass and height after planting, resulting in less height at the end of the experiment; although this did not entail more elevated mortality.

Species showing no effect of size (at least in survival) naturally grow in more xeric habitats of Chile, and probably are more drought resistant (S. polygamus and L. caustica). Those where plant size proved influential with or without irrigation ( $M$. boaria) are probably more water-demanding (Rodríguez et al. 1983, Armesto and Picket 1985). Thus, we suggest that size (or age) may be important to survival among the more water-demanding species.

Among semiarid ecosystems (e.g., Rey et al. 2009, Padilla and Pugnaire 2009), including central Chile (Armesto and Pickett 1985, Fuentes et al. 1986), establishment of most native tree species is facilitated by nurse pioneer shrubs, especially in more xeric conditions. This has been attributed primarily to higher soil moisture beneath the shrub canopy, compared to open areas (Fuentes et al. 1986, Del Pozo et al. 1989, Becerra et al. 2011). Similar relationships have also been observed for some tree species, even shade-intolerant ones used in our experiment (e.g., L. caustica, Q. saponaria, M. boaria and S. polyga- 


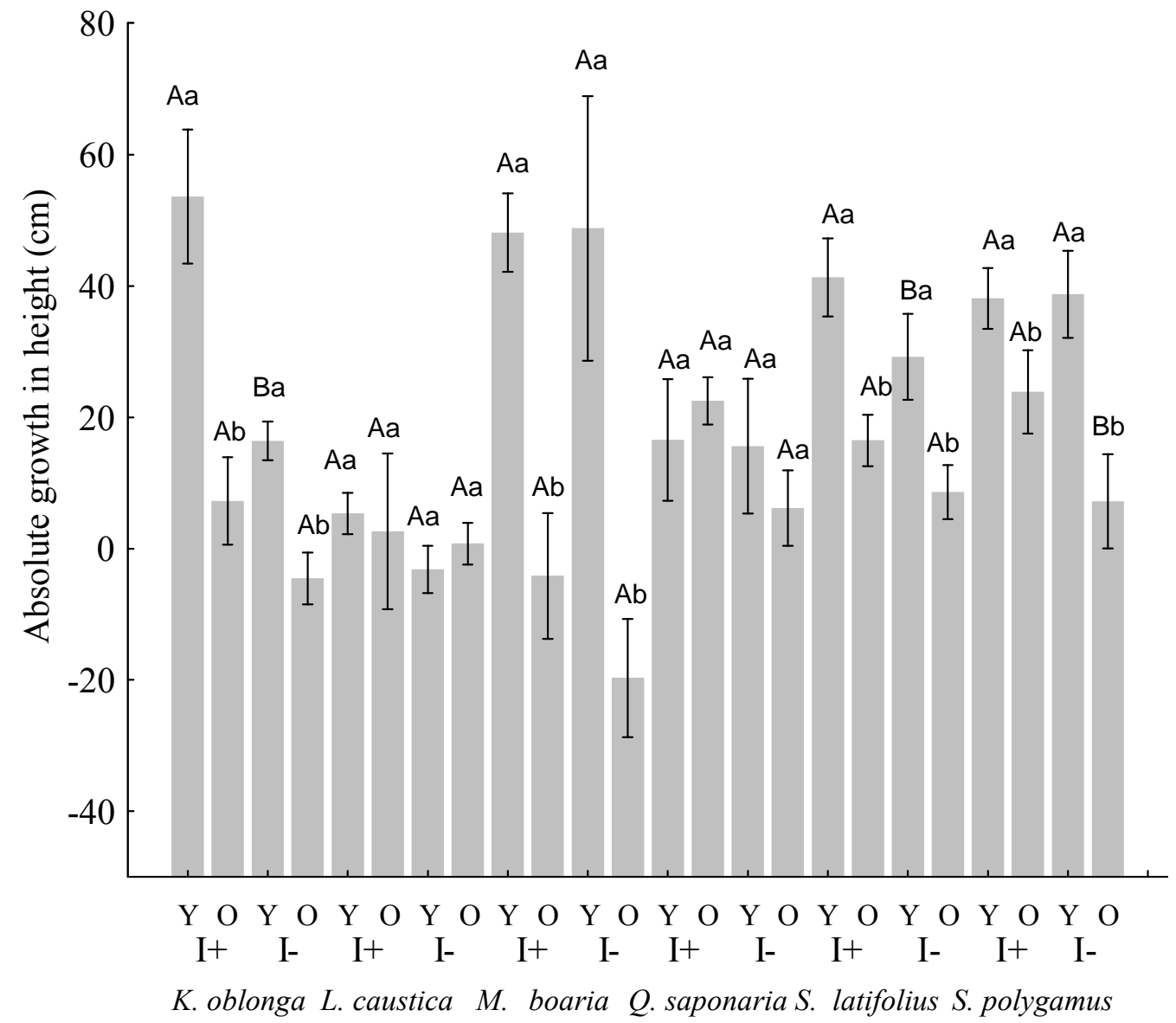

Figure 3. Absolute height growth in two years per species (mean $\pm 1 \mathrm{SE}$ ) (Y: smaller or 1-year-old plants; O: larger or 4 year-old plants; I+ with irrigation; I-: without irrigation). Different lower-case and upper-case letters indicate significant statistical differences (GLM, LSD post-hoc tests, $P<0.05$ ) between sizes within a single species and irrigation treatment and between irrigation treatments within a single species and size, respectively.

Tasa de crecimiento absoluto en altura en dos años por especie (media $\pm 1 \mathrm{EE}$ ) (Y: plantas pequeñas de un año; O: plantas grandes de cuatro años; I+: con riego; I-: sin riego). Diferentes letras minúsculas y mayúsculas indican respectivamente diferencias estadísticas significativas (GLM, test a posteriori LSD, $P<0,05$ ) entre tamaños de planta dentro de una particular especie y tratamiento de riego, y entre tratamientos de riego dentro de una particular especie y tamaño.

mus; Fuentes et al. 1986). Our results suggest that the use of larger plants and/or irrigation may improve survival in open areas and accelerate restoration without the necessity of establishing nurse pioneer shrubs before tree planting.

Our results apply to artificial establishments of trees in semiarid ecosystems with an oceanic influence, and especially to semiarid regions with reclaimed fly ash landfills (and perhaps after mining), including across the coastal Mediterranean region of Chile. Yet we cannot predict future outcomes from the plantation due to the relatively thin $(0.8 \mathrm{~m})$ substrate and possibly toxic effects of the ash residues on the trees (Haynes 2009). Fly ash has been toxic for some plants (Dellantonio et al. 2008, Haynes 2009); though this must yet be assessed for the full range of species used for restoration over a fly ash substrate. The fact that chemical properties in the upper soil horizon at the experimental site did not differ significantly from those at surrounding natural habitats (table 1) suggests that at least the upper soil stratum should prove suitable for initial survival and development. And while after two years the roots of most plants have not reached the ash substrate (personal observation), a fly ash substrate has not limited root penetration in other species (Neuschütz et al. 2006).

Our results suggest that irrigation and plant size may importantly affect the success of seedling survival and growth in restoration projects, but the effects vary across species. With drought-resistant species, irrigation and size seem unimportant for survival. Among water-demanding species, both irrigation and the use of larger plants would improve survival. For species classified in the middle of a water requirement gradient, irrigation seems necessary only with small plants. On the other hand, irrigation rather than using larger plants may improve growth in height, although this depends on the species. However, the effects of irrigation and the role of plant size on growth in height were not correlated to drought-resistance of species. For 
restoration on this type of substrate in the coastal area of central Chile, we advise planting mainly large (at least 4 year old) plants of $S$. latifolius and $S$. polygamus without irrigation. To increase species diversity restoration projects may use large plants of $K$. oblonga, $M$. boaria and $Q$. saponaria with irrigation during summer, and large plants of $L$. caustica without irrigation. Irrigation may be useful in S. latifolius, K. oblonga or S. polygamus only if increased height growth is required.

\section{ACKNOWLEDGEMENTS}

This study was supported by AES Gener S.A. We thank Mitiga Ltda. for the installation of the experiment and application of the irrigation during the study.

\section{REFERENCES}

Adriano DC, JT Weber. 2001. Influence of fly ash on soil physical properties and turfgrass establishment. Journal of Environmental Quality 30: 596-601.

Altamirano T. 2008. Restauración de los sistemas naturales mediterráneos de Chile central. Estudio de casos de restauración del bosque esclerófilo. Santiago, Chile. Tesis de Ingeniería Forestal, Facultad de Agronomía e Ingeniería Forestal, Pontificia Universidad Católica de Chile.

Armesto JJ, STA Pickett. 1985. A mechanistic approach to the study of succession in the Chilean matorral. Revista Chilena de Historia Natural 58: 9-17.

Becerra P, V González, C Smith-Ramírez, J Armesto. 2011. Spatio-temporal variation in the effect of the herbaceous layer on seedling survival of woody species in a semiarid ecosystem. Journal of Vegetation Science 22: 847-855.

Brinks JS, JM Lhotka, CD Barton, RC Warner, CT Agouridis. 2011. Effects of fertilization and irrigation on American sycamore and black locust planted on a reclaimed surface mine in Appalachia. Forest Ecology and Management 261: 640-648.

Del Pozo A, E Fuentes, E Hajek, J Molina. 1989. Zonación microclimática por efecto de los manchones de arbustos en el matorral de Chile central. Revista Chilena de Historia Natural 62: 85-94.

Dellantonio A, W Fitz, H Custovic, F Repman, B Schneider, H Grünewald, V Gruber, Z Zgorelec, N Zerem, C Carter, M Markovic, M Puschenreiter, W Wenzel. 2008. Environmental risks of farmed and barren alkaline coal ash landfills in Tuzla, Bosnia and Herzegovina. Environmental Pollution 153: 677-686.

di Castri F, E Hajek. 1976. Bioclimatología de Chile. Ediciones Universidad Católica de Chile. 128 p.

Fuentes ER, E Hajek. 1979. Patterns of landscape modifications in relation to agricultural practice in central Chile. Environmental Conservation 6: 265-271.

Fuentes ER, AJ Hoffmann, A Poiani, MC Alliende. 1986. Vegetation change in large clearings: patterns in the Chilean ma- torral. Oecologia 68: 358-366.

Haynes RJ. 2009. Reclamation and revegetation of fly ash disposal sites - Challenges and research needs. Journal of Environmental Management 90: 43-53.

Holmgren M, BC López, JR Gutiérrez, FA Squeo. 2006. Herbivory and plant growth rate determine the success of El Niño Southern Oscillation-driven tree establishment in semiarid South America. Global Change Biology 12: 2263-2271.

Lamhamedi MS, PY Bernier, C Hébert, R Jobidon. 1998. Physiological and growth responses of three sizes of containerized Picea mariana seedlings outplanted with and without vegetation control. Forest Ecology and Management 110: 13-23.

Lusk C. 2004. Leaf area and growth of juvenile temperate evergreens in low light: species of contrasting shade tolerance change rank during ontogeny. Functional Ecology 18: 820828 .

Neuschütz C, E Stoltz, M Greger. 2006. Root penetration of sealing layers made of fly ash and sewage sludge. Journal of Environmental Quality 35: 1260-1268.

Padilla FM, FI Pugnaire. 2009. Species identity and water availability determine establishment success under the canopy of Retama sphaerocarpa shrubs in a dry environment. Restoration Ecology 17: 900-907.

Pardos M, A Royo, JA Pardos. 2005. Growth, nutrient, water relations, and gas exchange in a holm oak plantation in response to irrigation and fertilization. New Forest 30: 75-94.

Radomiljac AM. 1998. The influence of pot host species, seedling age and supplementary nursery nutrition on Santalum album Linn (Indian sandalwood) plantation establishment within the Ord River Irrigation Area, Western Australia. Forest Ecology and Management 102: 193-201.

Rey PJ, JM Alcantara. 2000. Recruitment dynamics of a fleshyfruited plant (Olea europaea): connecting patterns of seed to seedling establishment. Journal of Ecology 88: 622-633.

Rey PJ, G Siles, JM Alcántara. 2009. Community-level restoration profiles in Mediterranean vegetation: nurse-based vs. traditional reforestation. Journal of Applied Ecology 46: 937-945.

Rey Benayas JM, A López-Pintor, C García, N de la Cámara, R Strasser, A Gómez. 2002. Early establishment of planted Retama sphaerocarpa seedlings under different levels of light, water and weed competition. Plant Ecology 159: 201-209.

Rodríguez R, O Matthei, M Quezada. 1983. Flora Arbórea de Chile. Concepción, Chile. Editorial de la Universidad de Concepción. 408 p.

Siles G, PJ Rey, JM Alcántara, JM Bastida, JL Herreros. 2010. Effects of soil enrichment, watering and seedling age on establishment of Mediterranean woody species. Acta Oecologica 36: 357-364.

Squeo FA, M Holmgren, J Milagros, L Albán, J Reyes, J Gutiérrez. 2007. Tree establishment along an ENSO experimental gradient in the Atacama desert. Journal of Vegetation Science 18: 195-202.

Van Andel J, L Aronson. 2006. Restoration Ecology. Oxford, UK. Blackwell Publishing. 340 p. 
